\title{
Analysis of a Global Green Transition
}

Niels I. Meyer, Ph.D., Dr. Techn.

Technical University of Denmark, Lyngby, Denmark

e-mail:nim@byg.dtu.dk

Keywords:

sustainable energy,

policy means,

green transition.
Mitigation of global warming and transitioning to a green and sustainable world are counteracted by a number of barriers and dilemmas. The paper analyzes a number of these barriers and dilemmas in order to highlight efficient strategies and solutions for a sustainable development. The dilemmas include the following examples:

- There are limits to economic and material growth in a finite globe, but most governments in industrial countries are calling for more growth in a period of financial crisis.

- More equity is required to stem the desire for growth, but inequity is increasing.

- The increase in global temperature should stay below two degrees centigrade in order to avoid irreversible consequences, but the present path points to four degrees or more.

- At least $50 \%$ of known reserves of fossil fuels must remain underground in order to avoid a temperature increase higher than two degrees, but a number of industrial countries are now promoting exploitation of new fossil sources like shale gas and oil from tar sand.

- Reversing population growth facilitates sustainable development, but most governments of industrial nations appear to be more concerned about decreases in their population.

\section{Introduction}

The world is presently faced with a number of serious problems including global warming and climate change, limits to economic and material growth, increasing inequities, misleading economic models and theories, and financial crises. Most national governments in the Organisation For Economic Co-Operation And Development (OECD) attempt to maintain traditional growth rates based on neoliberal principles. However, they do not appear to realize that a sustainable future requires radical changes in political, economic and institutional systems on international and national levels.

In relation to the problem of global warming, it has not been possible to date to obtain international commitments for binding reductions of $\mathrm{CO}_{2}$ emissions. However, there seems to be international consensus concerning the danger of irreversible consequences if the increase in global temperature is allowed to surpass two degrees centigrade. Recent analyses have concluded that in order to avoid this transition at least $50 \%$ of known fossil reserves should remain untapped underground [IEA, 2012]. It is not obvious how this condition would be implemented in practice. Moreover, with the recent exploitation of non-traditional energy sources like shale gas and shale oil, the goal of limited use appears to be even more problematic. This issue should be high on the agenda of the united nations (UN), but so far it is not the case.

This paper will focus on the role of the rich industrial countries, as they are responsible for most of the present problems. In addition, such countries have the necessary economic and technological power to implement a green transition to a world that is not dependent on fossil fuels.

However, it should not be overlooked that there are a number of barriers for this transition. Strong financial power is connected to vested interests in production of fossil fuels, while concern about sustainable development is relegated as a low priority on the money-based agenda. Here, significant changes are needed to yield 
less power to the market and private vested interests. The paper includes concrete proposals for such changes.

The implications of limits to growth in a finite world should be at the center of any strategy for a sustainable future. Unfortunately, that is not the case. Instead, it has become fashionable to speak of green growth in order to avoid taking the substance of limits to growth seriously. It will be argued in this paper that green growth in the present framework is an illusion and typically an excuse for continuing traditional growth with green cover.

The need for significant societal and institutional changes to implement a sustainable green transition to a world that is not dependent on fossil fuels is often neglected in comparison with the focus on new technological solutions. The focus of this paper is designed with the opposite priority.

\section{Limits To Growth}

Several pioneers of economics have warned that pursuing growth forever is not desirable [Mill, 1900; Keynes, 1931]. Growth should be considered as a temporary phase, until the global population has achieved satisfactory material welfare. The concept of limits to growth captured broad public interest with the publication of a report with the same name in 1972.

\subsection{The Limits to Growth report}

An extensive study of the "World Problematic" was initiated by The Club of Rome [Nørgård et al., 2010; Meyer, AtKisson, 2012], resulting in the 1972 report The Limits to Growth (LtG) [Meadows et al., 1972]. The report presents a number of scenarios based on an ag- gregated computer model, simulating the global development in population, food production, use of nonrenewable resources like fossil fuels, industrial output, and in environmental pollution.

The report concluded that continuation of the actual growth policies in population, industrialization, food production, and consumption of non-renewable resources would most likely lead to some kind of collapse during the 21th century, due to resource scarcity, over-pollution, over-population, etc. This collapse scenario attracted the most attention. However, alternative scenarios were also presented in the report illustrating how a change of course could lead to an environmentally sustainable development path, which is also able to satisfy all people's physical needs.

Many critics of the report focused exclusively on the collapse scenario, and stated by the 1990s that the collapse had failed to materialize. However, the analysis in that scenario finds the collapse to occur decades later [Nørgård et al., 2010]. The recent recognition of global warming from $\mathrm{CO}_{2}$ concentration in the atmosphere and an approaching peak in oil supply combined with the current financial crises fits rather well with the growth scenario in LtG. As shown in Fig. 1, real developments in the main parameters in LtG have followed quite closely the main trends in the report's standard (collapse) scenario, which leads to collapse around 2040 [Vuuren van, Faber, 2009; Turner, 2009]. See also the two later revisions of LtG [Meadows et al., 1992; Meadows et al., 2004]. Thus, the basis for the warnings from LtG remain and should be taken seriously before it is too late.
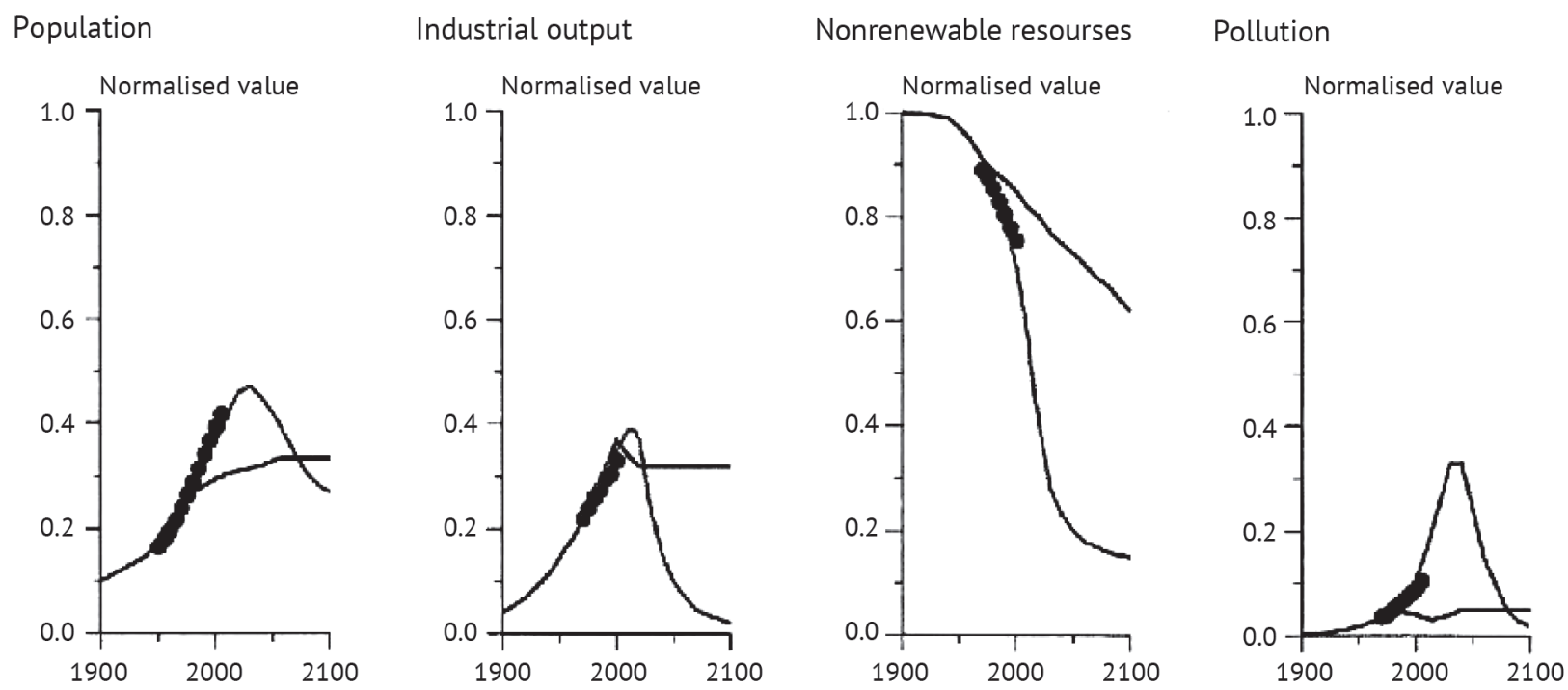

Figure 1. The observed global developments of four essential parameters, here shown as black dots, roughly follow the outcome in the Standard run with growth and collapse, rather than the Stabilized run from 'The Limits to Growth' model. [Vuuren van, Faber, 2009]. 


\subsection{The illusion of decoupling and green growth}

The so-called decoupling between GDP and energy consumption is a statistical myth or illusion based on macroeconomic abstractions [Nørgård, 2009], since all economic activities encompassed within GDP involve some energy consumption.

A growing GDP will always push energy consumption upwards, but this trend may be reduced for some time by savings from more efficient technologies. The coupling between GDP and energy consumption has clearly been demonstrated in real life by the drop in energy consumption during the recent recession in OECD countries. The use of the term decoupling has unfortunately led to the seductive perception of green growth, i.e. that GDP can grow in an unlimited way, without any impact on energy consumption. What can rightfully be claimed is that energy consumption need not grow at the same rate as the GDP.

A true decoupling between GDP and energy consumption is not possible, but it is possible to obtain decoupling between GDP and $\mathrm{CO}_{2}$ emission by shifting to an energy supply without $\mathrm{CO}_{2}$ emission. Based on the current path, however, even in the most optimistic case, this will not be achieved on a global scale before 2050 with serious climate change effects expected to occur during the period. Recognizing this, the concept of green growth is generally a dangerous and painted excuse to continue the present growth with minor corrections.

On a related count, it is worth underscoring that there will always be a coupling between human economic activities and environmental impact, since all energy supplies, including renewable energy sources, have some environmental impact.

\subsection{New paradigm of employment}

In a balanced economy, the number of working hours should be reduced with increasing productivity resulting in more free time for everybody.

One of the rationales for promoting continued economic growth in the present 'neoliberal economy' (discussed more fully below) is the employment effect of increasing productivity. Briefly sketched, the economic growth-employment idea works as follows. If productivity increases by $2 \%$ per year, there will be about $2 \%$ less jobs available next year, provided no new economic growth occurs. This proposition, however is flawed, as it assumes a fixed number of working hours per week which is not a natural law.

A solution which can account better for sustainable development and employment would introduce a flexible number of working hours per week, dependent on the state of the market. When there is a lack of jobs, the number of working hours is reduced, and vice ver- sa. This could be combined with work-sharing, so that forced unemployment is avoided. As the economist John Maynard Keynes expressed in the 1930s: "Take care of unemployment and the budget will take care of itself." In addition, this scheme will abolish the present inhumane system that locks millions of people in industrial countries into forced unemployment.

In rich countries this system could be supplemented by a general basic income (citizens salary) scheme securing more freedom for people to choose their individual life style [Meyer et al., 1981].

\subsection{Misleading economic models and theories}

A change in economic policy is required where the principles of ecological economy are given much higher priority. This is not a sufficient condition for sustainable development, but rather a necessary condition.

Prevailing ideas in neoclassical/neoliberal economics have been responsible for a number of financial crises since the 1980 s, with the present crisis from 2008 still ongoing. Recently, the two Nobel Prize winners in economy, Joseph Stiglitz and Paul Krugman, openly acknowledged that neoliberal economic theory and models have no real scientific basis and have been more harmful than useful. Other realistic economists have used the phrase that economy is politics in disguise [Chang, 2010].

It is high time that these disclosures are included in economic university education and are taken into account in government policies. One alternative is to focus on ideas from ecological economics rather than neoclassical/neoliberal economics. The main difference between these two systems is briefly described as follows, drawing upon Herman Daly's references to sustainable development [Daly, 2007].

Standard neoliberal economics (SNE) ideas are based on the premise of an isolated economic system with circular flow of production and consumption. SNE is primarily focused on efficient allocation of resources with minor attention to fair distribution and typically no attention to economic scale.

In contrast to this, ecological economics (EE) considers an economy to be an open subsystem of a finite, non-growing biosphere that is closed with respect to matter but open to a (non-growing) flow of solar energy. EE focuses first on the sustainability of the economic scale and its material through-put. Second priority is given to fair distribution, while efficient allocation is positioned still lower as a third priority.

Considered together, SNE is mainly concerned with the variation of a narrowly defined GDP, where depletion of natural capital and number of pollution effects are often not included as costs in the accounting. EE instead points out that growth in GDP may result in un- 
economic growth due to depletion of natural capital and pollution effects. Such a tendency towards uneconomic growth is already observed in some OECD countries [Daly, 2007]. Recent studies by economists and other researchers indicate that in societies where citizens' basic needs are met, further income and consumption will not increase people's satisfaction and happiness [Jackson, 2009; Layard, 2006; Jackson, 2005; Nørgård, 2006]. In other words, in affluent parts of the world, continued growth in GDP is not necessary for a good life.

Going further, SNE favors global economic integration based on free trade and free capital mobility with reference to the classical argument of "comparative advantage”. John Maynard Keynes pointed out in the 1930s that free capital movement destabilizes the national economic systems. He also proposed that independent national banks should control such capital movements in order to avoid destabilization of the economy. EE recognizes that the classical economics model did not include free capital movement and that internalization of environmental costs tends to be given low priority in a global race to cut costs and attract capital. Unfortunately, the EU has abolished this form of control in the 1980 s and made the free capital movement part of the EU constitution.

An important sustainability question then turns to intergenerational balance. In standard macroeconomic modeling, this is often settled by introducing discount factors for future economic events. However, discount factors of $4 \%$ or higher mean that the welfare of $\mathrm{fu}$ ture generations is given low priority Never-the-less, a number of governments in OECD countries have official discount factors in this range. In any case, the intergenerational balance cannot be satisfied by such a simple technical factor in economic models. The intergenerational distribution problem is a complex one and should recognize that that different generations may have different goals and priorities. The focus should not be on efficient allocation, but rather on keeping flexible choices and opportunities open for future generations.

\subsection{Global warming: Adaptation or mitigation?}

Investments in adaptation should not be allowed to reduce the necessary investments in mitigation.

Strategies for coping with global warming include both mitigation and adaptation. The former stems the tide of the shift, whereas the latter develops an altered way of dealing with the shift. As it is becoming more and more clear that the efforts to mitigate global warming are too weak and too slow, the general focus is to some extent moving from mitigation to adaptation. This may turn out to be an expensive and dangerous shift in strategy.

The British government's report on climate change [Stern, 2007] noted that costs can be expected to be an order of magnitude more expensive for the world to continue with a business as usual approach, rather than investing quickly and strongly in mitigation of global warming. This indicates that it may be a costly strategy to shift the emphasis from mitigation to adaptation. Increasing investments in adaptation with limited economic resources available in the present financial situation may further delay the necessary investments in mitigation.

The shift of investments from mitigation to adaptation may give rise to costly consequences if the global increase in temperature passes the critical two degrees centigrade sooner than expected.

It may be concluded, that investments in adaptation should be concentrated to the cheapest and most urgent projects in order to avoid costly investment failures.

\subsection{The importance of equity}

Equity is fundamental to the well-being of society.

There is solid documentation that societies with a high degree of economic and social equity are doing better on essential parameters like health, living standard, low criminality, low rates of suicide, high personal life satisfaction, high trade competitiveness etc. [Wilkinson, Pickett, 2009].

The degree of equity may be described by the socalled Gini-coefficient with values between zero and one. If the national income is divided equally between all citizens, the value is zero. If all of the national income goes to one person, the value equals one. As a rule of thumb, a society with a Gini-coefficient less than 0.3 can count on a rather solid social stability, while societies with values above 0.4 are in danger of running into serious social problems. The Nordic countries have Ginicoefficients between 0.23 and 0.25 , whereas the numbers for the US and South Africa are 0.45 and 0.65 respectively. Surprisingly, high equity is low on the priority list for many countries.

Comparatively speaking, the lack of equity between western industrial nations and developing nations is a serious barrier for commitments on international agreements concerning $\mathrm{CO}_{2}$ emission reductions. This issue should be taken more seriously by the international Conference of Parties on mitigation of global warming.

\section{Emission Trading Systems}

A principal approach to limit $\mathrm{CO} 2$ emissions centers on government caps for the allowed emissions from selected parts of industrial production or private households. Examples of such schemes follow.

\subsection{Industrial carbon quota}

The Emission Trading System has reflected unimpressive carbon savings to date. 
In effect for some time, the EU's Emission Trading System (ETS) embodies industrial carbon quotas. The ETS is designed so that energy-intensive industries (including electric utilities) are given carbon emission limits that are specified by the EU Commission and national governments. The experience with this cap-andtrade scheme to date has already revealed a number of shortcomings, resulting in unimpressive carbon savings within EU. It remains to be seen whether stricter caps and other reforms will produce the desired results during the second period of the scheme after 2013 [EU Commission, 2008]. So far, agreement about the strengthening of the ETS has been prevented by opposition from some member countries, especially Poland. However, the EU Commission continues to work on establishing constructive changes through consensus in the ETS.

\subsection{Personal carbon allowances}

Considering the slow progress in mitigation of climate change, the concept of Personal Carbon Allowances deserves further attention as a supplement to existing schemes.

Energy taxes and subsidy systems for energy conservation have so far not been efficient in convincing private households to implement sufficient building renovations and other forms of energy conservation.

One alternative proposal is called Personal Carbon Allowances (PCA) [Fawcett et al., 2009]. In the PCA scheme, every adult is allotted an equal, tradable ration of $\mathrm{CO} 2$ emission per year related to their consumption of selected energy services for private households. Compared to the cap-and-trade system used in the industrial sector, PCAs apply to individuals and influence their behavior. PCA establishes a direct mechanism with negligible uncertainty for emission reduction in the household sector. For simplicity, one proposal is that PCA should be related only to "direct" energy consumption, i.e., energy used for personal travel plus heating and electricity within the household [Fawcett et al., 2009].

So far, no country has introduced a PCA scheme and only a few industrial countries are giving serious consideration to the scheme. The most extensive discussion of PCA has taken place in the UK where UK's Department for Environment, Food and Rural Affairs (DEFRA) published a report on the scheme in 2008 [DEFRA, 2008] with a positive evaluation of its potential. A similar conclusion was expressed by the Chairman of UK's Environment Agency, Lord Smith of Finsbury, in a speech at the agency's annual conference in London in November 2009. In both cases it was stated that the scheme needs relative long time to develop and that the cost of administration should be analyzed more closely.

The efficiency of a PCA system is dependent on the particular energy system in the country and on the in- stitutional arrangements. Analysis of the potential of PCA in the UK and Denmark [Fawcett et al., 2009] indicates that for these two countries the scheme would cover 30 to $50 \%$ of the total national $\mathrm{CO}_{2}$ emissions. The PCA requires systematic government support to the households in order that they may benefit from the scheme and accept it as a positive challenge.

\section{Examples Of Solutions}

In this section, examples for international and national strategies are described. More details may be found in two recent books (Jackson, 2012; Meyer, 2012).

\subsection{International changes}

Existing international institutions, like the World Trade Organization (WTO), International Monetary Fund (IMF), and the World Bank, present serious obstacles for a sustainable development, since their policies and priorities have been closely linked to neoliberal theory and models [Jackson, 2012]. This reality has been harmful for sustainable development, especially for many developing countries.

In recent years, these international institutions have slowly begun to change their policies due to the unsatisfactory results. However, the basic rules for the institutions do not allow them to give sufficiently high priority to a sustainable green transition. Here, it is important to consider alternatives to the existing institutions [Jackson, 2012; Meyer, 2012].

\section{Alternative trade organization}

The main priority of the present WTO is to promote international trade and overcome barriers to free trade associated with customs duties on import or export subsidies. Concerns for the negative consequences of trade for the environment and social equity figure on a limited to non-existent basis within the WTO. The WTO's focus is based on the conception that free international trade is an advantage for all parties - in spite of solid documentation that this is not the case [Jackson, 2012]. Free trade favors advanced industrial countries and multinational companies. Free trade is also often a disadvantage for developing countries that cannot compete in the advanced technological arena or protect domestic efforts to build up competitive technologies.

When considering a green transition, the WTO presents a barrier to an efficient promotion of general global welfare, when welfare is defined to include environmental stewardship and social equity. This leads to the proposition that WTO should be replaced by a new international trade organization. Such replacement would be responsible for promoting environmental sustainable trade with fair rules that permit developing nations to protect their emerging technological development for 
a sufficient period [Jackson, 2012; Meyer, 2012]. The alternative organization could also be responsible for the administration of a general tax on financial transactions (i.e. Tobin tax).

Similar changes of priorities could be introduced in transformed versions of IMF and the World Bank as well, where global equity and sustainability can play a more defining role.

\section{Shale gas and oil from tar sand should remain under- ground}

During the last five years, the US has pioneered the exploitation of shale gas at scale. This has changed the entire energy sector in the US, with the cost of gas and coal decreasing significantly. In tandem with this, the US is becoming less dependent on imported fossil fuels and is expected to become an exporter of liquid natural gas.

It is not surprising that the U.S. government is supporting energy supply security and the accompanying financial advantages. However, from an environmental sustainability point of view, such exploitation of new non-traditional fossil fuels is alarming. Recent analyses have shown that to keep the global warming below the critical two degrees, at least $50 \%$ of known fossil fuels should be kept underground [IEA, 2012]. This is an extremely difficult objective to meet in practice - to use an understatement. If a general exploitation of shale gas all over the world is being implemented, it may be impossible to prevent the global temperature to increase above two degrees.

This issue merits attention by the United Nations to adequately limit the shale gas progression. Similar considerations apply to the exploitation of oil from tar sands. lem

Population declines are good news - not a new prob-

According to official UN estimates, the world population is on a trajectory with no adjustments to grow to around 9 billion by 2050. It turns out that with relatively small changes in number of births per woman, large changes are possible in the long term. Sustainability, including mitigation of climate change, would be a lot easier in a world with population numbers in the lower range of estimated scenarios.

Population is slowly declining in many parts of the Western world. However, government policies in these densely populated, high CO 2 emitting, countries often encourage higher birth rates rather than lower. This short-sighted policy is based on assumed problems when a decreasing number of young people in the work force have to support an increasing number of older people outside the active work force. This problem is, how- ever, relatively easy to overcome with long term planning and modifications in national policies. One of the consequences may be that future generations in OECD countries will not be much richer than the present generation, but this is in agreement with the basic concept of limits to growth.

Based on concerns for the consequences for human welfare and the environment, policies encouraging birth rates below 2.0 per woman could be promoted in poor as well as affluent countries. In the affluent countries, a population policy, which avoids economic and social incentives to increase birth rates, may be sufficient. In poorer countries, strategies like information campaigns about birth control for women may suffice, while in other cases, stronger means like economic incentives may be necessary. Population control is clearly a sensitive issue, and policies can conflict with basic ideas about personal freedom. They can also conflict with traditions and religious beliefs. Nevertheless, as indicated above, population policy should be part of any climate change policy.

\subsection{National changes}

New rules for democratic political work:

Democracy is being undermined by money power. This is a dangerous trend since democratic decisions should be based on informed arguments and not on narrow commercial interests. This complexity presents a serious barrier for a green transition. Here, radical reforms could include the following [Meyer, 2012]:

- It shall be forbidden by law for private persons, commercial companies and all kinds of organizations to offer economic support to political parties and politicians. The only exception is a modest fee for members of political parties e.g. of the order of $40 €$ per year.

- Governments should support the work of political parties with a membership above a minimum level with basic economic funding, but most of the political work must rely on voluntary efforts from the members.

These restrictions may meet a lot of resistance from vested interests in the present capitalistic system, but solutions along these lines are necessary if real democracy is to survive.

\section{Promotion of equity}

It was emphasized in an earlier section that a high degree of economic equity is important for a balanced economy without growth. This may be achieved by strongly progressive taxes on income, capital and inheritance above a certain minimum value. Such a scheme has recently been supported by the French economist Thomas Piketty [Piketty, 2014]. 
The fear that highly salaried commercial managers will emigrate in large numbers with such taxation schemes seems highly exaggerated in the media. However, it would be relevant to combine such schemes with reintroduction of national control of capital movements.

\section{Constraints from international agreements}

Some relevant changes like national control of capital movements will, however, be in direct conflict with the EU constitution. Thus, it would not be possible for member states of EU to reintroduce national control with capital movements as the EU constitution emphasizes free capital movement. Such members would have to negotiate a different relationship with the EU to make this change. This subject will be further discussed in section 6 .

\section{The Necessary Technologies Are There}

The only energy technologies deserving the name sustainable are based on renewable sources used for solar heating and cooling, photo-voltaics (PVs), wind power, wave power etc. A number of these technologies are already competitive with energy technologies using fossil fuels, especially when including externalities. In practice, these externalities are far from included in the cost of fossil fuels creating an unbalanced competition system. In contrast, the global state subsidies for fossil fuels are an order of magnitude larger than the support for renewables. The lack of political will and policies for a balanced market are delaying the necessary green transition.

In order to promote renewable energy sources a number of government supported tariff systems have been introduced e.g. for wind power in Europe. The most efficient one has turned out to be the so-called feed-in tariff [Meyer, 2007].

The renewable energy sources are characterized by their intermittent nature which complicates establishing balance between supply and demand and requires new systems thinking. However, a recent Danish energy project with the title "Coherent Energy and Environmental System Analysis" (CEESA) has documented that it is possible to phase out all fossil fuels in Denmark with known technologies before 2050. Compared to business as usual approach, this green scenario will have lower total costs over the period [CEESA, 2012].

The technological innovation includes production of higher energy efficiency motors, cars, trains, and household equipment like refrigerators and lighting [Nørgård et al., 2007]. One should be aware, however, that the full technical efficiency improvement is seldom evident in actual use when human beings are the main actors because of the rebound effect. When cars run longer per liter of fuel, many people will enjoy longer trips. When refrigerators are more energy efficient, people may buy larger refrigerators. When low energy lighting is introduced, people may use more lights and leave them on during the night. It is possible to reduce the consequences of this effect by changing life styles [Nørgård, 2009], but the effect should be taken into account when planning future energy systems.

The green transition involves new planning methodologies and new policy means as described in the reports from CEESA. Similar kinds of strategies may be used for a green transition in most industrial countries, but this will probably not gain momentum at scale in time without establishing a lead group of motivated and technological advanced countries.

\section{How To Get Started?}

To date, the global society has not been able to create sufficient international co-operation to avoid serious climatic consequences from man-made global warming. The good news is that alternative systems and policies using existing technologies could provide the necessary solutions, should the industrial nations decide to use these opportunities efficiently. Time is at a premium, however, and new types of international co-operation and economic systems are needed.

A possible lead group may be the Nordic countries. They have already initiated a number of concrete policies supporting sustainable development and a green transition. In addition, they have a long tradition of close co-operation and recent analyses point to many advantages of some kind of Nordic union [Wetterberg, 2010]. It would require, however, that Denmark, Finland and Sweden obtain a more flexible type of EU membership in order to be free and independent of several constraints in the EU constitution [Meyer, 2012]. Alternatively, these three countries would have to give up their membership of the EU. The lead group should be open to other nations with the same goal.

An important economic barrier is due to the present system of free capital movement which is part of the EU constitution. This undermines the stability of national economy and national control of such financial transactions should be reintroduced for the lead group.

Such changes would involve extensive formal negotiations between the lead group and the EU. As both parties have obvious advantages of continued co-operation there is no reason to believe that a satisfactory kind of co-operation could not be attained.

Without the formation of such a lead group of countries speeding up the green transition, this transition may not be realized in time to avoid a number of serious negative consequences of climate change. 
Научные основы формирования техносферы Scientific Bases of Technosphere Formation

\section{Conclusions}

Limited progress toward a sustainable green transition is not tied to a scarcity of low-carbon technologies, but rather to the adherence to economic and political systems with short-sighted vested interests and inappropriate priorities. In spite of this, most scientific pa-

\section{REFERENCES}

1. CEESA Project (2012). Aalborg University, Denmark, www.ceesa.dk

2. Chang H-J (2010). 23 Things They Don't Tell You About Capitalism. Penguin Books, London, UK.

3. Daly HE (2007). Ecological Economics and Sustainable Development. Edward Elgar Publishers, Mass., USA.

4. DEFRA (2008). Synthesis report on the findings from DEFRA's pre-feasibility study into personal carbon trading. London: Department for Environment, Food and Rural Affairs, UK.

5. EU Commission (2008). Questions and Answers on the Commission's proposal to revise the EU Emissions Trading System. MEMO/08/35, January 2008, Bruxelles, Belgium.

6. Fawcett T., Hvelplund F., Meyer N.I. (2009). Making it personal: Per capita carbon allowances? In Generating Electricity in a Carbon Constrained World, edited by Fereidoon P. Sioshansi, Elsevier Publishers, Holland.

7. IEA (2012). World Energy outlook 2012. Paris, France.

8. Jackson R. (2012). Occupy Wall Street. Chelsea Green Publishing, Vermont, USA.

9. Jackson T. (2005). Live better by consuming less? Is there a 'double dividend' in sustainable consumption? Journal of Industrial Ecology,9 (1-2), pp. 19-36.

10. Jackson T. (2009). Prosperity without Growth - Economics for a Finite Planet. Earth Scan, London, UK.

11. Keynes J.M. (1931). Essays in Persuasion. Milland and $\mathrm{C}^{\circ}$., London, UK.

12. Layard R. (2005). Happiness - Lessons from a New Science. Penguin Books, London, OK.

13. Meadows D.H., Meadows D.L., Randers J., Behrens W.W. (1972). The Limits to Growth. Potomac Associates Publishers, Washington DC, USA.

14. Meadows D.H., Meadows D.L., Randers J. (1992). Beyond the Limits. Chelsea Green Publishing Co., Postmills, VT, USA.

15. Meadows D.H., Randers J., Meadows D.L. (2004). Limits to Growth. The 30 Year Update. Chelsea Green Publishing Co., Postmills, VT, USA.

16. Meyer N.I. (2007). Learning from Wind Energy Policy in the EU: Lessons from Denmark, Sweden and Spain. European Environment 17, pp. 347-362.

17. Meyer N.I. (2012). Enough is Enough - Stop the NonSustainable Development/ (in Danish)/ 17. 18. Tiderne Skifter Publishers, Copenhagen, Denmark. pers on sustainable energy development are focusing on technological aspects, while neglecting the importance of societal policy changes. This is the reason that the present paper has focused on policy means for a green transition and given less attention to the sustainable energy technologies.

18. Meyer N.I., Petersen K.H., Sørensen V. (1981). Revolt from the Center. Marion Boyars Publishing, London, UK.

19. Meyer N.I., Hvelplund F., Nørgård J.S. (2011). Equity, Economic Growth and Lifestyle. In Energy Sustainability and the Environment: Technology, incentives, behavior, F. Sioshnsi (ed.). Elsevier, Netherlands.

20. Meyer N.I., Atkinson A. (2012). From Sustainability Science to Real-World Action: A Short History of the

21. Balaton Group.Solutions, 3, issue 5, September-October. 2012, pp. $75-81$.

22. Mill J.S. (1900). Principles of Political Economy (original version published in 1848). Revised edition, Vol. II, Colonial Press, New York, USA.

23. Nørgård J.S. (2006). Consumer efficiency in conflict with GDP growth. Ecological Economics, 57, pp. 15-29.

24. Nørgård J.S., Brange B., Guldbrandsen T., Karbo P. (2007). Turning the Appliance Market around towards A++. Proceedings of the European Council for an Energy Efficient Economy, Summer Study 2007, Stockholm: ECEEE, pp. 155-164.

25. Nørgård J.S. (2009). Avoiding Rebound through a Steady State Economy. In: Energy Efficiency and Sustainable Consumption. The Rebound Effect. Herring, $\mathrm{H}$ \& Sorell, S. (eds.). Ch. 10, 204-223. Palgrave Macmillan, UK.

26. Nørgård J.S., Peet J., Ragnarsdóttir K.V. (2010). The history of The Limits to Growth. Solutions, vol. 1, No. 2, March-April, pp. 59-63. http://www.thesolutionsjournal. com/node/569.

27. Piketty T. (2014). Capital in the Twenty-First Century. Belknap Press, US.

28. Stern N. (2007). The Economics of Climate Change: the Stern Review. Cambridge University Press, Cambridge, Storbritannien, 2007.

29. Turner G.M. (2009). A Comparison of the 'Limits to Growth' with 30 Years of Reality. Global Environmental Change (in press). http://www.csiro.au/files/files/plje. pdf.

30. UNEP (2008). Reforming Energy Subsidies. United Nations Environment Programme. Division of Technology, Industry and Economics, New York, USA.

31. UN Population Division (2008). World Population Policies 2007. Department of Economic and Social Affairs. United Nations, New York, USA. http://www.un.org/esa/ population/publications/wpp2007/Publication_index. htm. 
Научные основы формирования техносферы Scientific Bases of Technosphere Formation

32. Vuuren D.P. van, Faber A. (2009). Growing within Limits - A Report to the Global Assembly 2009 of the Club of Rome. The Netherlands Environmental Assessment Agency. Bilthoven, The Netherlands. http://www.rivm. nl/bibliotheek/rapporten/500201001.pdf.
33. Wetterberg G. (2010). A Nordic Union/ (in Danish)/ published by the Nordic Council of Ministers,

34. Copenhagen, Denmark.

35. Wilkinson R., Pickett K. (2009). The Spirit Level. www. equalitytrust.org.uk.

\section{Анализ глобального «зеленого» перехода}

Нильс И. Мейер, профессор Датского технического университета, Люнгбю-Торбек, Дания

Смягчению глобального потепления и переходу к «зеленому» и устойчивому миру противостоят ряд барьеров и дилемм. В настоящей работе предпринят анализ некоторых барьеров и дилемм с целью выделения эффективных стратегий и решений для достижения устойчивого развития. В качестве примеров дилемм выделены следуюшие.

- На физически конечной планете существуют пределы экономического и материального роста. Однако в большинстве индустриально развитых стран в условиях кризиса правительства призывают к дальнейшему росту.

- Для ограничения роста требуется равенство, между тем в мире возрастает неравенство.

- Для того чтобы избежать необратимых изменений, необходимо, чтобы увеличение средней глобальной температуры не превысило $2^{\circ} \mathrm{C}$. Между тем, наблюдаемые в настоящее время тенденции обусловливают увеличение на 4 и более градусов.

- Для того чтобы избежать роста средней глобальной температуры более чем на $2^{\circ} \mathrm{C}$, по крайней мере 50\% разведанных запасов ископаемого топлива должны оставаться в земных недрах. Между тем ряд индустриально развитых стран стимулируют освоение новых ископаемых энергетических ресурсов, таких как сланцевый газ и нефть битуминозных песчаников.

- Прекращение роста численности населения облегчает переход к устойчивому развитию. Однако большинство правительств развитых стран выражают крайнюю обеспокоенность в связи со снижением численности населения в своих странах.

- Центральной проблемой является тот факт, что «пределы роста» не воспринимаются серьезно финансовыми ведомствами индустриально развитых стран. Настоящая статья посвящена рассмотрению последствий «пределов роста» и поискам альтернативы «росту» для обеспечения занятости населения.

Ключевые слова: устойчивая энергетика, политические средства, «зеленый» переход.

\section{В России запущен первый завод по производству солнечных батарей}

Завод полного цикла по производству солнечных модулей был запущен в эксплуатацию 17 февраля в Новочебоксарске (Чувашия). Производимые солнечные батареи можно будет использовать и в пасмурную погоду.

Суммарный объем инвестиций в создание производства и инженерной инфраструктуры составил 20 млрд руб. Премьер-министр Дмитрий Медведев принял участие в запуске производства на заводе. Завод начнет работать на полную мощность $(97,5 \mathrm{MBT}$ в год) во второй половине 2015 года. На предприятии используется тонкопленочная технология производ- ства солнечных модулей методом напыления нанослоев, позволяющая в 200 раз сократить использование кремния - основного сырья в солнечной энергетике.

Солнечные модули, производимые в Новочебоксарске, способны вырабатывать электричество даже в пасмурную погоду, что особенно актуально для российских условий.

Солнечные панели, выпускаемые заводом, будут в основном использоваться для выработки электроэнергии для потребителей в отдаленных регионах в качестве объектов малой энергетики.

Источник: www. GreenEvolution.ru. 